\title{
Effect of Millets Intercropping Systems on Pest Incidence and Sustained Productivity of Castor (Ricinus communis L.)
}

\author{
N. Prajwal* and S.B. Kalaghatagi \\ Department of Agronomy, College of Agriculture, Vijayapura University of Agricultural \\ Sciences, Dharwad -580 005, Karnataka India \\ *Corresponding author
}

\section{A B S T R A C T}

\section{Keywords}

Castor, Millets,

Semilooper,

Capsule borer, Tillers

\section{Article Info}

Accepted:

17 November 2019

Available Online:

10 December 2019
A field experiment was conducted during kharif season of 2017-18 at College of Agriculture, Vijayapura, in medium black soils to study the performance of castor (Ricinus communis L.) based millets intercropping systems under rainfed condition. The experiment was laid out in Randomized block design. The results indicated that sole castor recorded significantly higher seed yield $\left(2416 \mathrm{~kg} \mathrm{ha}^{-1}\right)$ and higher number of capsules per plant and capsule weight per plant $\left(293.25\right.$ plant $\left.^{-1}\right)$ than the other intercropped castor and lower capsules per plant (143.84 plant $\left.^{-1}\right)$ was recorded in castor intercropped with pearl millet in 1:2 row proportion. Among intercrops sole foxtail millet recorded higher number of productive tillers (63.00). At harvest higher total dry matter accumulation was recorded in sole castor $\left(379.41 \mathrm{~g} \mathrm{plant}^{-1}\right)$ and among intercrops sole pearl millet recorded higher total dry matter production $(57.16 \mathrm{~g}$ plant $\left.^{-1}\right)$. Among different intercropping systems the incidence of semilooper and percent capsule borer were found to be lower in castor + foxtail millet ( 9.66 larvae plant $^{-1}$ and $8.79 \%$, respectively) in 1:2 row proportion while, sole castor recorded higher incidence of semilooper and capsule borer damage (14.23 larvae plant ${ }^{-1}$ and $16.84 \%)$, similarly castor + little millet $(1: 2)$ recorded higher castor equivalent yield $\left(3325 \mathrm{~kg} \mathrm{ha}^{-1}\right)$ and higher net returns $\left(78,720 \mathrm{Rs} \mathrm{ha}^{-1}\right)$.

\section{Introduction}

Intercropping of different cereals, millets, pulses and oilseed crops simultaneously on the same piece of land with or without any row proportion will minimizes the risk of crop failures, acts as barrier for pests, builds soil fertility and makes the farmer self-sufficient. It is often stated that pests will be less damaging in fields with a mixture of crops than in fields with a single sole crop, also known as monocultures. Castor is an important oil seed crop and millets are known as famine reserves as they can come up well in low moisture conditions. They are highly nutritive and are having short duration, to make better utilization of resources and space millets are well suited for intercropping 
systems. There is little scope to bring additional area under these crops due to stiff competition from major cereals and other commercial crops. Thus, in absence of possibilities for horizontal expansion, the vertical expansion of castor yield through intercropping with millets offering varying competition in space and time enhances the productivity.

The castor, Ricinus communis L., is a species of perennial flowering plant in the spurge family, Euphorbiaceae.. Castor is indigenous to the south eastern Mediterranean Basin Eastern Africa and India but, it is widespread throughout tropical regions. Castor seed is the source of castor oil which has a wide variety of uses. The seeds contain between 40 to 60 per cent oil that is rich in triglycerides mainly ricinolein. The seed also contains ricin, a water-soluble toxin, which is also present in lower concentrations throughout the plant. In the world, castor is cultivated around $1.26 \mathrm{~m}$ ha with a production of $1.78 \mathrm{mt}$ with average productivity $1414 \mathrm{~kg} \mathrm{ha}^{-1}$ (FAOSTAT, 2016). In India castor is cultivated around $0.87 \mathrm{~m}$ ha with a production of $1.55 \mathrm{mt}$ with average productivity $1786 \mathrm{~kg} \mathrm{ha}^{-1}$ (FAOSTAT, 2016) and Gujarat accounts 73 per cent of production and 56 per cent total area of the country. In Karnataka, castor crop is cultivated around 0.16 lakh hectare with a production of 0.14 lakh tonnes with a productivity of $926 \mathrm{~kg}$ ha $^{-1}$ (Anon., 2016).

Similarly, intercropping of millets with castor delayed the succession of almost all the major pests. Intercropping leads to higher yields and increase the economic returns and greater crop equivalent yield as compared to sole cropping.

\section{Materials and Methods}

Field experiment was conducted during the rainy season (kharif -2017-18) at the Agricultural College, Vijayapura, Karnataka on Vertisol having pH 7.55 and EC $0.4 \mathrm{dS} \mathrm{m}^{-1}$. The soil was medium in organic carbon content $(0.53 \%)$ and available $\mathrm{P}_{2} \mathrm{O}_{5}(25.60 \mathrm{~kg}$ $\left.\mathrm{ha}^{-1}\right)$ and low in available $\mathrm{N}\left(215.00 \mathrm{~kg} \mathrm{ha}^{-1}\right)$ with available $\mathrm{K}$ content (384.00) and clay content (47.20).

The experimental site was located at a latitude of $16^{0} 55^{1}$ North, longitude of $75^{0} 58^{1}$ East and an altitude of 444.39 meters above mean sea level. The experimental site comes under the Northern Dry Zone of Karnataka (Zone 3)

There were eleven treatments as detailed in Table 1 i.e. intercropping of castor with pearl millet, finger millet, foxtail millet, little millet and proso millet in 1:2 proportion and six sole crops and their duration (castor 48-1 and 180 days), pearl millet (ICMV-221 and 90 days), finger millet (DHFMV-78-3 and 110-115 days), foxtail millet (DHFT-109-3 and 80 days), little millet (DHLM-36-3 and 75-80 days) and proso millet (DHP-2769 and 70 days).

The experiment was laid out in randomized complete block design with three replications in plot size of $9 \mathrm{~m} \mathrm{x} 6 \mathrm{~m}$.

Both the component crops were planted simultaneously and recommended dose of fertilizers were applied to all crops as per the recommended package of the region.

In intercropping system, the component crops received fertilizers in proportionate to their plant density at the time of sowing in the form of urea, DAP and muriate of potash.

The crops were sown as per the row proportions in intercropping systems and as well as their sole during the period of I fortnight (FN) of July i.e on $11^{\text {th }}$ July 2017 during kharif 2017 when field was attained optimum moisture conditions and total rainfall received during cropping season was 590.3 
$\mathrm{mm}$ i.e in July, August, September, October, November, December and Janaury $(74.0 \mathrm{~mm}$, $161.0 \mathrm{~mm}, 188.3 \mathrm{~mm}, 148.8 \mathrm{~mm}, 0.0 \mathrm{~mm}, 18.2$ $\mathrm{mm}$ and $0.0 \mathrm{~mm}$ respectively). The growth and yield observations were recorded from the net plot size and grain yield of various crops were converted to hectare basis in kilograms. The economics of each system was computed with prevailing market prices of that year.

\section{Results and Discussion}

\section{Effect of intercropping on insect pest incidence}

The data presented in Table 1, revealed that, among the various intercropping systems tried with castor at 1:2 row proportions. Significantly lower semilooper incidence was noticed at 60, 75 and 90 days after sowing (8.80, 12.33 and 7.86 larvae plant $^{-1}$, respectively) and capsule borer incidence $(8.79 \%)$ were found in castor + foxtail millet compared to sole castor and other intercropping systems while, sole castor recorded significantly higher incidence of semilooper (16.53, 18.78 and 11.93 larvare plant $^{-1}$, respectively) and percent capsule borer damage (16.84).

This might be due to pest migration after initial establishment was possibly inhibited by non host plants act as a physical barrier to inter or intra row migration within intercropping treatments as a result of finding difficulties of host experienced in castor intercropped with millets grown in 1:2 row ratio. Similar results were reported in castor + cluster bean (Rao et al., 2012) system.

Castor + pigeonpea intercropping system (Chand and Sujatha, 2000). Similarly in chickpea significantly lower pod damage was recorded in chickpea + sunflower in $(5: 1)$ intercropping system $(19.50 \%)$ compared to sole chickpea (Pattar et al., 2012)
Effect of intercropping on growth parameters, yield parameters and net returns of intercropping system

The data presented in Table 2 revealed that, among the various intercropping systems tried with castor at 1:2 row proportions, castor recorded higher total dry matter production in sole castor (379.41 $\mathrm{g}$ plant $^{-1}$ ) when compared with rest of the intercropping systems and lowest was recorded in castor + pearl millet (203.52 $\left.\mathrm{g} \mathrm{plant}^{-1}\right)$ in 1:2 row proportion and among intercrops sole pearl millet recorded higher dry matter (57.16 $\left.\mathrm{g} \mathrm{plant}^{-1}\right)$.

This might be due to competition for growth resources between two crops at initial stage led to competition for moisture and nutrients favoured better availability of moisture and nutrients for both the crops in a system. The results are in conformity with the findings of Veeranna (2003). Similar results were recorded in castor intercropped with mungbean reported by Kumawat and Adreshna (2014) and koli et al., (2004).

Higher number of productive tillers was noticed in sole millets compared to intercrops. Among different crops foxtail millet recorded higher number of productive tillers both in sole and intercropping condition (63.00 and 57.67 tillers plant $^{-1}$ ). This was mainly due to good rainfall distribution and better utilization of resources in sole crop when compared to intercropping systems (Triveni et al., 2017).

Among the various intercropping systems tried with castor at 1:2 row proportions, castor recorded higher yield $\left(2283 \mathrm{~kg} \mathrm{ha}^{-1}\right)$ with little millet, when compared with rest of the intercropping systems this might be due to least competition for growth resources between two crops at initial stage led to no competition for moisture and nutrients favoured better availability of moisture and nutrients for both the crops in a system. 
Table.1 Incidence of semilooper and capsule borer damage in castor as influenced by various intercropping system (1:2)

\begin{tabular}{|c|c|c|c|c|c|}
\hline \multirow[t]{2}{*}{ Treatments } & \multicolumn{4}{|c|}{$\begin{array}{c}\text { Semilooper incidence } \\
\left.\text { (number of larvae plant }{ }^{-1}\right)\end{array}$} & \multirow[t]{2}{*}{$\begin{array}{l}\text { Capsule borer } \\
\text { incidence }(\%)\end{array}$} \\
\hline & 60 DAS & 75 DAS & 90 DAS & Average & \\
\hline $\begin{array}{c}T_{1} \text {-Castor + Pearl millet } \\
(1: 2)\end{array}$ & $\begin{array}{l}13.07 \\
(3.68)^{*}\end{array}$ & $\begin{array}{l}15.95 \\
(4.05)^{*}\end{array}$ & $\begin{array}{c}9.90 \\
(3.23)^{*}\end{array}$ & 12.97 & $\begin{array}{l}13.88 \\
(21.10)\end{array}$ \\
\hline $\begin{array}{c}T_{2}-\text { Castor }+ \text { Finger millet } \\
(1: 2)\end{array}$ & $\begin{array}{l}12.46 \\
(3.60)^{*}\end{array}$ & $\begin{array}{l}15.07 \\
(3.94)^{*}\end{array}$ & $\begin{array}{c}9.20 \\
(3.11)^{*}\end{array}$ & 12.24 & $\begin{array}{l}11.36 \\
(20.47)^{* * *}\end{array}$ \\
\hline $\begin{array}{c}T_{3}-\text { Castor + Foxtail millet } \\
(1: 2)\end{array}$ & $\begin{array}{c}8.80 \\
(3.05)^{*}\end{array}$ & $\begin{array}{l}12.33 \\
(3.58)^{*}\end{array}$ & $\begin{array}{l}7.86 \\
(2.89)^{*}\end{array}$ & 9.66 & $\begin{array}{l}8.79 \\
(18.10)^{* * *}\end{array}$ \\
\hline $\begin{array}{c}T_{4}-\text { Castor }+ \text { Little millet } \\
(1: 2)\end{array}$ & $\begin{array}{l}10.27 \\
\left(3.28^{*}\right.\end{array}$ & $\begin{array}{l}13.86 \\
(3.79)^{*}\end{array}$ & $\begin{array}{c}8.93 \\
(3.07)^{*}\end{array}$ & 11.02 & $\begin{array}{l}9.25 \\
(19.38)^{* *}\end{array}$ \\
\hline $\begin{array}{c}\mathrm{T}_{5}-\text { Castor }+ \text { Proso millet } \\
(1: 2)\end{array}$ & $\begin{array}{l}11.23 \\
(3.43)^{*}\end{array}$ & $\begin{array}{c}14.30 \\
(3.85)^{*}\end{array}$ & $\begin{array}{c}9.03 \\
(3.09)^{*}\end{array}$ & 11.52 & $\begin{array}{l}9.44 \\
(19.83)^{* *}\end{array}$ \\
\hline $\mathbf{T}_{6}$-Sole Castor & $\begin{array}{l}16.53 \\
(4.13)^{*}\end{array}$ & $\begin{array}{l}18.78 \\
(4.39)^{*}\end{array}$ & $\begin{array}{l}11.93 \\
(3.52)^{*}\end{array}$ & 14.23 & $\begin{array}{l}16.84 \\
(23.37)^{* * *}\end{array}$ \\
\hline $\mathbf{T}_{7}$-Sole Pearl millet & - & - & - & - & - \\
\hline $\mathbf{T}_{8}$-Sole Finger millet & - & - & - & - & - \\
\hline $\mathbf{T}_{9}$-Sole Foxtail millet & - & - & - & - & - \\
\hline $\mathbf{T}_{10}$-Sole Little millet & - & - & - & - & - \\
\hline $\mathrm{T}_{11}$-Sole Proso millet & - & - & - & - & - \\
\hline S.Em \pm & 0.27 & 0.42 & 0.33 & & 0.44 \\
\hline C.D. $(5 \%)$ & 0.81 & 1.24 & 0.98 & & 1.30 \\
\hline
\end{tabular}

* - Angular transformed values 
Table.2 Growth parameters, yield parameters and net returns of castor based millets intercropping systems

\begin{tabular}{|c|c|c|c|c|c|c|c|c|}
\hline \multirow[t]{2}{*}{ Treatments } & \multicolumn{2}{|c|}{ 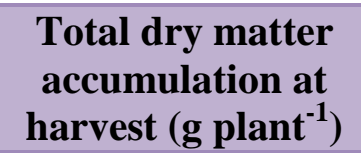 } & \multirow{2}{*}{$\begin{array}{c}\text { Number } \\
\text { of } \\
\text { productive } \\
\text { tillers at } \\
\text { harvest }\end{array}$} & \multirow{2}{*}{$\begin{array}{l}\text { Number } \\
\quad \text { of } \\
\text { capsules } \\
\text { per plant }\end{array}$} & \multicolumn{2}{|c|}{ Yield $\left(\mathrm{kg} \mathrm{ha}^{-1}\right)$} & \multirow{2}{*}{$\begin{array}{c}\text { Castor } \\
\text { equivalent } \\
\text { yield } \\
(\mathrm{CEY})\end{array}$} & \multirow[t]{2}{*}{$\begin{array}{c}\text { Net } \\
\text { returns } \\
\left(\mathrm{Rs} \mathrm{ha}^{-1}\right)\end{array}$} \\
\hline & Castor & millets & & & Castor & Intercrop & & \\
\hline $\begin{array}{c}T_{1}-\text { Castor + Pearl millet } \\
(1: 2)\end{array}$ & 203.52 & 49.33 & 37.00 & 143.84 & 1454 & 1273 & 2003 & 39742 \\
\hline $\begin{array}{c}T_{2}-\text { Castor }+ \text { Finger } \\
\text { millet }(1: 2)\end{array}$ & 231.10 & 17.00 & 46.67 & 158.00 & 1705 & 1386 & 2696 & 55328 \\
\hline $\begin{array}{c}T_{3}-\text { Castor + Foxtail } \\
\text { millet }(1: 2)\end{array}$ & 276.64 & 16.93 & 57.67 & 223.60 & 1923 & 1730 & 3159 & 73134 \\
\hline $\begin{array}{c}T_{4}-\text { Castor }+ \text { Little millet } \\
(1: 2)\end{array}$ & 334.48 & 16.35 & 56.67 & 263.94 & 2283 & 1458 & 3325 & 78720 \\
\hline $\begin{array}{c}\mathrm{T}_{5}-\text { Castor + Proso } \\
\text { millet (1:2) }\end{array}$ & 302.61 & 12.07 & 50.00 & 231.40 & 2112 & 1400 & 3112 & 71259 \\
\hline $\mathbf{T}_{6}$-Sole Castor & 379.41 & - & - & 293.25 & 2416 & - & 2416 & 49726 \\
\hline $\mathbf{T}_{7}$-Sole Pearl millet & - & 57.16 & 39.00 & - & - & 1659 & 711 & 9237 \\
\hline $\mathbf{T}_{8}$-Sole Finger millet & - & 18.55 & 47.67 & - & - & 2082 & 1487 & 18790 \\
\hline $\mathbf{T}_{9}$-Sole Foxtail millet & - & 17.59 & 63.00 & - & - & 2431 & 1736 & 30893 \\
\hline $\mathbf{T}_{10}$-Sole Little millet & - & 17.13 & 61.00 & - & - & 2293 & 1638 & 27443 \\
\hline $\mathbf{T}_{11}$-Sole Proso millet & - & 13.88 & 51.67 & - & - & 2068 & 1477 & 22394 \\
\hline S.Em \pm & 5.71 & & & 7.07 & 54 & & 72 & 2409 \\
\hline C.D. $(5 \%)$ & 16.85 & & & 20.86 & 158 & & 212 & 7108 \\
\hline
\end{tabular}


The seed yield of sole castor $\left(2416 \mathrm{~kg} \mathrm{ha}^{-1}\right)$ was higher than that of the castor in rest of the intercropping systems. This might be due to fact that component crop compete for all growth resources both on above and below ground. Among the intercrops foxtail millet, recorded higher grain yield $\left(1730 \mathrm{~kg} \mathrm{ha}^{-1}\right)$ as compared to other millets. Among millets sole foxtail millet recorded higher grain yield (2431 kg ha-1).

The results are in conformity with the findings in castor based intercropping systems (Guggari and Kalaghatagi, 2010) and aslo with the findings of Ramachadrappa et al., (2016)

The castor equivalent yield (CEY) and land equivalent ratio (LER) differed significantly due to intercropping treatments. The data indicated that, significantly higher castor equivalent yield (3325 kg ha ${ }^{-1}$ ) was obtained with castor + little millet which was on par with castor + foxtail millet $\left(3159 \mathrm{~kg} \mathrm{ha}^{-1}\right)$. The higher castor equivalent yield was due to higher additional grain yield from little millet. The results are in conformity with findings of Thanunathan et al., (2006).

Significantly higher net returns was found in castor + little millet $\left(78,720 \mathrm{Rs} \mathrm{ha}^{-1}\right)$ compared to sole castor and other intercropping systems which was on par with castor + foxtail millet $\left(73,134 \mathrm{Rs} \mathrm{ha}^{-1}\right)$ in 1:2 row proportion this might be due to higher yield in castor intercropped with little millet and foxtail millet led to higher net returns and B:C. These results are in confirmatory with castor + green gram intercropping system (Mudalagiriyappa et al., 2011) and in pigeonpea + soybean intercropping system by Halvankar et al., 2000.

From the above study it can be concluded that among various intercropping system both semilooper incidence and percent capsule borer damage was found lowest in castor + foxtail millet (9.66 larvae plant ${ }^{-1}$ and 8.79, respectively) and highest in sole castor (14.23 larvae plant-1 and $16.84 \%$ ). Growing of castor with little millet at 1:2 row proportion recorded higher castor equivalent yield (3325 $\mathrm{kg} / \mathrm{ha})$ compared to sole castor seed $(2416 \mathrm{~kg}$ / ha). Castor + little millet intercropping system is more remunerative over sole cropping. Therefore we conclude that castor + little millet (1:2) intercropping system for northern dry zone of Karnataka under rainfed condition.

\section{Acknowledgments}

The study was funded Department of Agronomy, College of Agriculture, Vijayapura, UAS Dharwad for their valuable input and contributions to research.

\section{References}

Anonymous, 2016, Oil seed data base, Indian Institute of Oilseed Research, Hyderabad. pp. 89-95.

FAOSTAT, 2016, The food and agriculture organization corporate statistical database, accessed on 2018 April 30, http//www.Fao.Org/faostat/en/\#data.

Chand P. and Sujatha, M. 2000. Castor based intercropping systems. Agric. Rev., 21 (4): 244-248.

Guggari A K. and Kalaghatagi S B. 2010. Castor based intercropping systems on vertic inceptisols under rainfed conditions. Indian J. Dryland Agric. Res. Dev., 25(2): 78-81.

Halvankar, G B. Varghese P. Taware S P. and Raut V M. 2000. Evaluation of intercropping patterns of soybean in pigeonpea. Indian J. Agron., 45: 530533.

Koli B D. Kate R N. Deshpande, A N. and Bangar A R. 2004. Intercropping of vegetables in redgram based cropping 
system in inceptisols under dryland conditions. Indian J. Dryland Agric. Res. Dev., 18 (2): 107-112.

Kumawat A K. and Adreshna. 2014. Response of castor (Ricinus communis L.) to row spacing and intercropping with mungbean (vigna radiata L.) during rabi season (doctoral dissertation, Agronomy Dept., NM College of Agriculture, Navsari Agricultural University, Navsari).

Mudalagiriyappa, Nanjappa $\mathrm{H} \quad \mathrm{V}$. Ramachandrappa B K. and Sharath Kumar H C. 2011. Productivity and Economics of Castor (Ricinus communis L.) based Intercropping Systems in Vertisols under Rainfed Conditions. Indian J. Dryland Agric. Res. Dev., 26 (2): 77-81.

Pattar P S. Mansur C. P. Alagundagi, S C. and Karabhantanal S S. 2012. Effect of intercropping systems on gram pod borer Helicoverpa armigera hubner and its natural enemies in chickpea. Indian J. Entomon., 74(2): 136-141.

Ramachandrappa B K. Timmegowda M N. Satish A. Dhanapal and Ravikumar H
S. 2016. Effect of intercropping in nipped castor (Ricinus communis L.) under rainfed conditions. Indian $J$. Dryland Agric. Res. \& Dev., 31(1): 3036.

Rao M S. Rama rao C A. Srinivas K. Pratibha G. and Venkateshwara B. 2012. Intercropping for management of insect pests of castor (Ricinus communis) in the semi-arid tropics of Indian. J. Insect Sci., 12: 14.

Thanunathan K. Malarvizhi S. Thiruppathi M. and Imayavaramban V. 2006. Economic evaluation of castor based intercropping systems. Madras $J$. Agric. Sci., 95(1/6): 38-41.

Triveni U. Sandhya Rani Y. Patro, T S S K. Anuradha N. and Divya M. 2017. Evaluation of different finger millet based intercropping systems in the north coastal zone of Andhra Pradesh. IJCS, 5(5): 828-831.

Veeranna G. 2003. Performance of castor Intercropped with vegetables under rainfed conditions. Ph.D. Thesis, PJTSAU, Hyderabad, Telangana (India).

\section{How to cite this article:}

Prajwal, N. and Kalaghatagi, S. B. 2019. Effect of Millets Intercropping Systems on Pest Incidence and Sustained Productivity of Castor (Ricinus communis L.). Int.J.Curr.Microbiol.App.Sci. 8(12): 2169-2175. doi: https://doi.org/10.20546/ijcmas.2019.812.257 